\title{
THE INFORMATION NEEDS OF CANCER PATIENTS IN THE PRETORIA AND WITWATERSRAND AREA
}

\author{
HA McLoughlin and BL Oosthuizen
}

\begin{abstract}
More than 48500 South Africans annually are confronted with the diagnosis of cancer. (Sitas, 1994) Judging from the literature it would seem that the acquisition of information about the various aspects of their disease is a very important coping mechanism for the cancer patient. Various studies concerning the information needs of cancer patients have been published in the USA, the UK and Australia. Similar studies have not yet been published in South Africa.
\end{abstract}

In this article the information needs of cancer patients in South Africa are tabulated based upon research done for the fulfillment of requirements for a Masters degree in Information Studies at the Rand Afrikaans University. Information Services available to these patients are then also described in detail.

Because of the sensitive nature of the subject questionnaires were compiled in co-operation with medical professionals who treat cancer patients. The questionnaire mainly concentrates on the physical and therapeutic aspects of the disease. Surgery, radiation therapy and chemotherapy are looked at.

The research population consisted of 200 cancer patients who were receiving treatment at various treatment centres in the Pretoria -Witwatersrand area. The statistical processing of the results confirmed that the majority of the cancer patients need detailed information about the various aspects of their disease. For example more than $75 \%$ of respondents indicated that they would like to receive detailed information about reasons and possible side effects as well as ways of minimising the side effects of all the treatment methods ranging from diagnostic tests to surgery as well as radiotherapy and chemotherapy.

Above $80 \%$ of respondents wanted to be informed about the possible success rate of surgery, radiation therapy and chemotherapy in their specific cancer. It is interesting to note that $78.5 \%$ of the respondents wished to be informed about the prognosis/survival rate of their specific cancer. The two preferred methods of communication indicated were firstly personal contact and then a combination of personal contact and booklets.

An important conclusion which can be reached is that co-operation between the medical professionals, the information services and the patient and his family is essential if the information needs of the cancer patient are to be met satisfactorily.

\section{OPSOMMING}

Meer as 48500 Suid-Afrikaners word jaarliks gekonfronteer met die diagnose : kanker. Uit die literatuur blyk dit dat inligting oor die verskillende aspekte van die sieke ' $n$ baie belangrike hulpmiddel vir die pasient is in die hantering van sy siekte. Verskillende studies is al in lande soos die Verenigde State van Amerika, Australie en Groot-Brittanje gedoen oor die inligtingsbehoeftes van kankerpasiente en hulle families. Soortgelyke studies is nog nie in Suid-Afrika gepubliseer nie.

In hierdie artikel word die inligtingsbehoeftes van kankerpasiente in Suid-Afrika getabuleer soos bevind in navorsing gedoen ter vervulling van die vereistes vir ' $n$ Magister graad in die Departement Inligtingstudies aan die Randse Afrikaanse Universiteit. Inligtingsdienste beskikbaar aan die pasiente in Suid-Afrika word ook dan in detail beskryf.

Vanwee die sensitiewe aard van die onderwerp is die vraelys ontwikkel met die samewerking van medici wat kanker pasiente behandel. Met die vraelys word veral gekonsentreer op inligtingsbehoeftes in verband met die fisiese en terapeutiese aspekte van die sieke. Chirurgie, chemoterapie en radioterapie word gedek.

Die proefpersone het bestaan uit 200 kankerpasiente wat behandeling ontvang het by verskillende sentra in die Pretoria-Witwatersrandgebied. Die statistiese verwerking van die resultate het bevestig dat die oorgrote meerderheid van kankerpasiente ' $n$ behoefte het aan gedetailleerde inligting oor verskillende aspekte van hulle siekte. Meer as $75 \%$ van respondente het byvoorbeeld aangedui dat hulle gedetaileerde inligting oor die redes en moontlike newe effekte sowel as metodes om die newe effekte teentewerk van al die behandelings metodes van diagnostiese toetse tot chirurgie, chemoterapie en radioterapie wil ontvang. Meer as $80 \%$ van die respondense het aangedui dar hulle ingelig wil word oor die moontlike sukses van chirurgie, chemoterapie en radioterapie op hulle spesifieke kanker. Dit is interessant dat $78.5 \%$ van die respondente ingelig wil word oor die prognose van hulle spesifieke kanker. Die twee metodes van kommunikasie wat verkies word is eerstens persoonlike kontak en dat persoonlike kontak gekombineerd met pamflette. ' $n$ Belangrike gevolgtrekking wat gemaak word is dat samewerking tussen die mediese professie, die verskillende inligtingsdienste en die pasient 


\section{INTRODUCTION}

Cancer is a word in the English language capable of striking fear into even the bravest of hearts. According to the report of the Cancer Registry of South Africa for 1989 , more than 48500 new cancer patients were diagnosed during that year. Although up to date statistics are not available as yet, it is reasonable to say that this figure can be safely projected to the present.

Each of these 48500 newly diagnosed cancer patients will experience the fear traditionally instilled by this diagnosis. Lee, editor of the Medical Association of South Africa publications, points out that, as in most other dimensions of human experience, fear is always much worse if based upon ignorance.

A literature study made clear that the health care profession's approach to the patient with cancer has changed over the past decade. The trend in recent years has been one of greater patient participation in illness management decisions. In order for the patient to be able to participate positively in this process, he has to be provided with accurate information in the appropriate language at the appropriate time in the course of his illness.

This article aims to describe what the information needs of the South African cancer patient are in order to facilitate the provision of such information at appropriate times. A further aim is to describe the information services available to the cancer patient in South Africa.

\section{METHODS USED IN THE STUDY}

Because of the sensitive nature of the subject it would have been impossible to complete the study without the co-operation of several health care professionals in the cancer field. By combining input from these health case professionals with guidelines from a literanure review, a structured questionnaire was designed. A chronological study of literature pertaining to the information needs of cancer patients demonstrates the growing importance of this aspect of patient care as an integral part of the treatment of the patient as a whole.

The content of the questionnaire was compiled using a combination of interviews conducted with the oncologists and doctors working in oncology surgery and guidelines from the literature.

Using the Derdiarian Needs Assess Instrument devised by Derdiarian (1986) as a basis, the questionnaire was compiled. According to this instrument the areas which need to be addressed are:

i) Disease-related concerns such as diagnosis, treatments and prognosis.

ii) Personal concerns such as physical and psychological well- being, job/career. iii) Family related concerns including spouse, parents, children and siblings.

iv) Social concerns such as contractual, leisure and intimate relationships.

The five main subjects of enquiry to the Cancer Information Service in the United States as described by Meissner (1990:173) were then compared to the categories described by Derdiarian (1986) and three additional aspects which needed to be investigated were identified

i) Referral/second opinion - names of doctors available for second opinions.

ii) Counselling services - telephone numbers of counselling services and support groups.

iii) Clinical trials in which patients can participate.

Adams (1991) describes what the content of education programmes should be. She focuses on the information/education needs of the patient during the following five phases of the disease:

i) Diagnosis

ii) Treatment

iii) Rehabilitation and continuing care

iv) Cancer survivorship/remission

v) Recurrence or advanced disease

Adams concentrates on the practical information needed by patients such as side effects, pain management and physical limitations due to the disease.

Frith (1991) stresses the importance of written materials which should be made available and Schulmeister (1991:122) lists numerous teaching tools and methods like video tapes and booklets which can be used to educate the patient. It is important to ascertain which format the patient would prefer and therefore questions which address this aspect should be included.

Additional aspects were highlighted by the health care professionals interviewed:

i) Information about complementary therapies such as aroma therapy and reflexology.

ii) Counselling in conjunction with written material

Using the guidelines for designing a questionnaire as set out by Berdie and Anderson (1974) and combining these with the above aspects as depicted in the literature and interviews, a questionnaire was developed.
The questionnaire is divided into three main sections and covers the following aspects:

Section A

Sociographic data

Data on cancer site

Treatment modalities which the patient has undergone or is undergoing

Section B:

Physical nature of cancer

Prognosis

Information resources available to the patient

Self help/support groups

Diagnostic tests : all aspects pertaining to these tests

Surgery : all aspects pertaining to surgery

Radiation therapy : all aspects pertaining to radiation therapy

Chemotherapy : all aspects pertaining to chemotherapy

Complementary therapies

All forms of treatment available to patients

Counselling services available

Clinical trials

Second opinions

"Miracle" / "fad" cures

Spiritual and religious guidance

Diet and nutrition

Medical aid coverage

Health care system

Section C:

Communication with family members, friends and colleagues

Knowledge of services of CANSA

\section{THE SAMPLE}

The questionnaires were sanctioned by the ethics committees of the HF Verwoerd Hospital and the University of Pretoria, the Johannesburg General Hospital and the University of the Witwatersrand as well as the heads of the radiation therapy section of Sandton Oncology Clinic and the Rand Clinic. 
Table 1 : Information needs of 200 cancer patients in the Pretoria and Witwatersrand area (a)

\section{QUESTION:}

\section{DO YOU WISH TO BE} INFORMED ABOUT ........?

Not at all

DIAGNOSTIC TESTS

Reason for diagnostic tests

Possible side effects of tests

3

Defin itely

$$
1
$$

$2.5 \%$

$15 \%$

$0.5 \%$



$2 \%$

4

$4.5 \%$

$3 \%$

$74.5 \%$

$92 \%$

\section{SURGERY}

Success rate of surgery in specific cancer

Need to provide booklet/

pamphlet explaining

pre-operative procedures

Possible physical disfigurement

from operation

\section{RADIATION THERAPY}

Success rate of radiation on specific cancer

$3.5 \%$

$5 \%$

$4 \%$

$5 \%$

Treatment schedule to

be discussed

Minimising of side effects due

to radiation therapy

$3.5 \%$

$2 \%$

$3.5 \%$

$3 \%$

$88 \%$

$1.5 \%$

$5.5 \%$

$3.5 \%$

$86 \%$

$5.5 \%$

$1 \%$

$3 \%$

$1.5 \%$

$89 \%$

\section{CHEMOTHERAPY}

Success rate of chemotherapy in specific cance

$9.5 \%$

Whether chemotherapy is

having desired effect

Option of stopping treatment

if not having desired effect

Minimising side effects due

to chemotherapy

$7.5 \%$

$7 \%$

$7.5 \%$

$7 \%$

$0.5 \%$

0

\section{GENERAL}

Prognosis / Survival rate

Details of Information

Resources in South Africa

Self help / patient support

groups

Complimentary therapies

All current forms of

treatments in South Africa

Councelling Services available

in South Africa

Clinical trials pertaining to specific cancer

Names of doctors / specialists for second opinions

Methods used in "fad"

treatment or "miracle" cures

\begin{tabular}{rrrrr}
$11 \%$ & $2 \%$ & $6.5 \%$ & $2 \%$ & $78.5 \%$ \\
$19 \%$ & $3.5 \%$ & $10.5 \%$ & $10 \%$ & $57 \%$ \\
$24 \%$ & $5.5 \%$ & $14.5 \%$ & $4.5 \%$ & $51.5 \%$ \\
$11.5 \%$ & $2 \%$ & $8.5 \%$ & $9.5 \%$ & $68.5 \%$ \\
$5.5 \%$ & $1.5 \%$ & $9 \%$ & $4 \%$ & $80 \%$ \\
$11 \%$ & $3.5 \%$ & $10 \%$ & $8.5 \%$ & $67 \%$ \\
$5 \%$ & $3 \%$ & $9 \%$ & $6.5 \%$ & $76.5 \%$ \\
$5 \%$ & $3 \%$ & $4.5 \%$ & $7.5 \%$ & $80 \%$ \\
$31.8 \%$ & $3.7 \%$ & $14.1 \%$ & $7.1 \%$ & $43.4 \%$ \\
& & & & \\
$14.2 \%$ & $4.6 \%$ & $11.2 \%$ & $5.6 \%$ & $64.5 \%$ \\
\hline
\end{tabular}

\section{COMMUNICATION}

Resources available for help with communication

$\begin{array}{rrr}6.5 \% & 3 \% & 81 \% \\ 10.5 \% & 2 \% & 80.5 \% \\ 8 \% & 2.5 \% & 81.5 \% \\ 8.5 \% & 1 \% & 83.5 \%\end{array}$

The research was started in 1993 and completed in 1994. The sample was made up of 200 patients being treated at the above centres. All questionnaires were handed to the patients personally at the treatment centres with a $100 \%$ response rate. There was an even spread of private and "hospital" patients as the questionnaires were completed at both Government Hospitals as well as private oncology clinics; $39 \%$ of the patients were

\section{Sociographic Data}

The mean age of the group was 48 , with the eldest being 85 and the youngest 13 .

Most towns in the Pretoria-Johannesburg area were represented.

Both male and female respondents were represented.

\section{RESULTS OF THE STUDY}

The main body of the questionnaire can be divided into four main sections according to the format of the questions asked. These sections are subdivided according to the various diagnostic procedures and treatment modalities (Table 1 - 4)

It is clear that most respondents wish to be informed about all aspects pertaining to the diagnosis of their disease and the various treatment modalities. Where psychosocial aspects are concerned it is interesting to note that respondents showed less interest in receiving information about self help/support groups and details of information resources available to them. Another aspect which many respondents do not want information about is that of "fad" treatments or "miracle" cures. Many respondents show a great interest in obtaining information about clinical trials which pertain to their specific cancer.

Many respondents indicate that they would like to receive a great deal of information about the physical nature of their cancer as well as various aspects of the different treatment modalities.

Religious/spiritual guidance during the course of the disease is seen as being crucial to most respondents. Communication about their disease is crucial to most respondents where the spouse and children are concerned. Communication with colleagues is not seen as crucial to many respondents.

\section{METHODS OF COMUNICATION}

According to the frequency study, personal contact is the preferred method of receiving information about the disease. A combination of personal contact and booklets was indicated as being the second most preferred method.

\section{CONCLUSIONS}

The results of this study clearly indicate that patients with cancer require a substantial amount of information about their disease and its treatment. The nature of the specific disease as well as all aspects of treatment as outlined in the tables need to be discussed with the patient. Personal communication with a member of the health care team as well as written information to enhance the 
TABLE 2 : Information needs of 200 cancer patients in the Pretoria and Witwatersrand area (b)

QUESTION: HOW MUCH INFORMATION DO

YOU REQUIRE ABOUT ........?

\section{PHYSICAL NATURE \\ OF CANCER}

Written information about

physical nature of specific

cancer

16. $5 \%$

$1 \%$

$8 \%$

$4.5 \%$

$70 \%$

SURGERY

Detail about pre-operative procedures

RADIATION THERAPY

Purpose of Radiation therapy

Effects (what it does) of

Radiation therapy

Treatment procedure followed

by the radiation therapist

Possible side effects of

radiation therapy

\section{CHEMOTHERAPY}

Purpose of chemotherapy

Effects (what it does) of

chemotherapy

Treatment procedure used

by oncologist

Side effects of chemotherapy

Diet while undergoing

chemotherapy

$4 \%$

$1.5 \%$

$10.5 \%$

$8 \%$

$76 \%$

$5 \%$

$0.5 \%$

$6.5 \%$

$5 \%$

$83 \%$

$5 \%$

$1 \%$

$6 \%$

$3 \%$

$85 \%$

$4 \%$

$5 \%$

$6.5 \%$

$9.5 \%$

$78.5 \%$

$5 \%$

$1 \%$

$4 \%$

$2.5 \%$

$86.4 \%$

$10.3 \%$

$1.5 \%$

$6.7 \%$

$2.6 \%$

$78.5 \%$

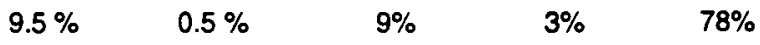

$6 \%$

$8.5 \%$

$10.5 \%$

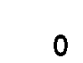

$6.5 \%$

$8 \%$

$4 \%$

$83.5 \%$

$4 \% \quad 79.5 \%$

\section{GENERAL}

Diet and nutrition after

treatments have been

completed

$4 \%$

$1.5 \%$

$7 \%$

$11.6 \%$

$75.9 \%$

Coverage of specific

medical aid for cancer care

$17.6 \%$

0

$4 \%$

$7.5 \%$

$70.9 \%$

Table 3 : Information needs of 200 cancer patients in the Pretoria and Witwatersrand area $(c)$

QUESTION: HOW MUCH DETAIL DO YOU

REQUIRE ABOUT

No
Det ail

1

DIAGNOSTIC TESTS

Procedure used during

diagnostic tests

Results of diagnostic tests

\begin{tabular}{rrrrr}
$5.5 \%$ & $1 \%$ & $5 \%$ & $6 \%$ & $82.5 \%$ \\
0 & $0.5 \%$ & $4 \%$ & $6.5 \%$ & $89 \%$ \\
\hline
\end{tabular}

Table 4 : Information needs of 200 cancer patients in the Pretoria and Witwatersrand area (d)

\section{QUESTION: HOW IMPORTANT IS THE}

FOLLOWING ASPECT TO YOU?

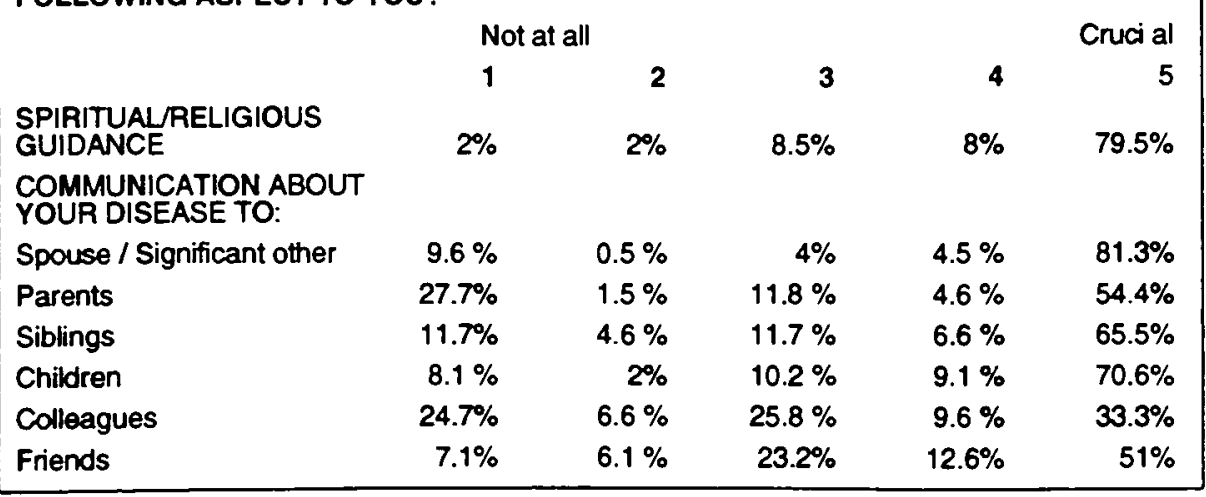

information clearly is a preference with most patients.

These conclusions are in line with findings of Lancaster (1980); Reynolds (1981); Derdiarian (1986, 1989); Freimuth (1989); Meissner (1990); Adams (1991); Frith (1991); Schulmeister (1991).

Respondents definitely want to receive full details about the procedures used during diagnostic tests and also the results of such tests.

\section{Final Reflections}

From the literature study conducted it is clear that the trend in recent years has been one aimed at greater openness between the doctor and the patient. Despite this trend, however, patients still express the need for more information about most aspects of their disease as indicated by the results of the empirical study. Respondents indicated that they need a great deal of information about most aspects covered in the empirical study. The lowest percentage of respondents, namely $43 \%$, indicated that they definitely wanted information about fad treatments. This was the lowest percentage recorded. Most of the questions, however, revealed that the percentage of respondents who wanted information about the various aspects was above $70 \%$, with many above the $80 \%$ mark. By equipping the health care professional with skills in communication and information provision, this need can be met.

The results of this study can be used to good effect by health care professionals dealing with cancer patients.

The role which the Cancer Association of South Africa as well as the other information services available in South Africa can play in the provision of information to the cancer patient cannot be stressed enough. Co-operation between CANSA, CISS (Cancer Information \& Support Service) and the various health care professionals needs to be expanded. CANSA and CISS already have the basic information provision structures in place and there is generally a good relationship between CANSA and CISS and the various health care professionals, both in government-run institutions as well as the private sector. However, the specific information service offered by CANSA needs to be promoted more. Further study to evaluate the services of fered at present is needed so that further recommendations can be made.

This study clearly highlights that fact that there is great need for structured information provision to the cancer patient in South Africa. In order to meet the needs of the patients as illustrated by the empirical study. co-operation between the various role-players in the cancer field is of paramount importance. 


\section{REFERENCES}

ADAMS, M (1991) : Information and education across the phases of cancer care. Seminars in oncology nursing. 7(2) 1991 : 105-111

BERDIE, DR \& ANDERSON, J F (1974) : Questionnaires : Design and use. Metuchen: The Scarecrow Press.

DERDIARIAN, A K (1989) : Effects of information on recently diagnosed cancer patients and spouses satisfaction with case. Cancer Nursing. 12 (5) 1989 : 285-292.

DERDIARIAN, A K (1986) : Informational needs of recently diagnosed cancer patients. Part 1. - Cancer Nursing 10(2) 107-115 1987.

DERDIARIAN, A K (1986) : Informational needs of recently diagnosed cancer patients. Nursing Research. 35(5) October 1986: 27.

FREIMUTH, V S et al (1989) : Searching for health information. The cancer information service model. Philadelphia: Univ. of Pennsylvania Press.

FRITH, B (1991) : Giving information to radiotherapy patients. Clinical oncology. 5(34) May 15 1991: 33-35.

LANCASTER, J (1986) : Should we tell the patient? Nursing RSA. 1(6) 1986: 31-32

LEE, N C (1990) : A new look at cancer. MASA Publications 1990.

MEISSNER, H I et al (1990) : Meeting information needs of significant others: Use of the Cancer Information Service. Patient Education and Councelling. 15 1990: 171-179.

REYNOLDS, M (1978) : No news is bad news : Patient's views about communication in hospital. British Medical Joumal. 1 1978: 1673-1676

SCHULMEISTER, L (1991) : Establishing a cancer patient education system for ambulatory patients. Seminars in oncology nursing. 7(2) 118-124.

SITAS, F \& PACELLA, R E : Incidence and Geographical Distribution of Histologically Diagnopsed Cancer 1989. JHB : S A M R : 1994

Heather A McLoughlin - M.Bibl Research Assistant Faculty of Medicine UNIVERSITY OF PRETORIA

Brendien L Oosthuizen - D Litt et Phil Information Studies

RAND AFRIKAANS UNIVERSITY 